\title{
Effect of Modified Ice Storage on the Shelf-life of Shrimp
}

\author{
Ming-Lang Ho,* Hsiu-Ho Cheng,* and Shann-Tzong Jiang* \\ (Accepted May 23, 1985)
}

\begin{abstract}
In order to keep the quality of shrimp during ice storage, a mixture of crushed ice, salt and some chemicals were employed. The quality of shrimp during storage was evaluated by means of the volatile base nitrogen (VB-N), extractive-nitrogen (AA-N), VB-N/AA-N ratio, indole, inosine monophosphate ratio (IMP ratio), bacterial count and sensory quality. It was found that using crushed ice containing 3 and $7 \% \mathrm{NaCl}$ extended the shelf-life of shrimp by 8 and 6 days, longer than that in the case of crushed ice alone. When $0.1 \% \mathrm{~K}$-sorbate, or $0.1 \% \mathrm{~K}$-sorbate, $0.05 \%$ Na-polyphosphate and $0.05 \% \mathrm{Na}$-pyrophosphate were added to crushed ice, the microbial growth and autolysis of shrimp meat retarded significantly. Crushed ice mixed with combination of $3 \%$ $\mathrm{NaCl}$ and $0.1 \% \mathrm{~K}$-sorbate, or $3 \% \mathrm{NaCl}, 0.1 \% \mathrm{~K}$-sorbate, $0.05 \% \mathrm{Na}$-polyphosphate and $0.05 \%$ Na-pyrophosphates showed better effects extending the shelf-iife of shrimp to 17 days. This dramatic effect can decrease the post-harvest loss of shrimp.
\end{abstract}

Decomposition and darkening discoloration are well-known serious problems in the preservation of shrimp and prawn. ${ }^{1-\theta}$ The darkening discoloration of shrimp during ice storage was ascribed to an enzymatic pathway where tyrosine and tyrosine-like compounds are oxidized in the presence of phenolase and oxygen and finally produce melanin, a dark pigment. ${ }^{3,5-8)}$ So far, much efforts have been made to present the development of darkening discoloration. ${ }^{10-18)}$ Although the addition of sodium bisulfite shows excellent effects on inhibiting the darkening discoloration, the sulfur dioxide residue is still a safety problem because of the formation of formaldehyde during storage. ${ }^{14,15)}$

Decomposition was considered to be due to delayed postharvest handling and mishandling during storage and processing. ${ }^{\theta, 16,17)}$ Although Savagaon et al. $^{20,21)}$ and Kumata et al. ${ }^{22}$ hinted the importance of radiation preservations of seafoods, it is still hard to be accepted by fishermen. This is because most of the fishermen are unaware of these sophisticate treatments.

This study was conducted to develop a convenient and effective method to preserve the shrimp and consequently to a better quality frozen product.

\section{Materials and Methods}

Shrimp Metapenaeopsis barbata used in this study was purchsed from a fishery market in northern Taiwan. They were immediately trans- ported to the laboratory with sufficient icing. These samples were iced for about $24 \mathrm{~h}$ before study.

Effect of Mixtures of Crushed Ice and Salt on the Storage Life of Shrimp

Samples were divided into 3 groups. Sample A (control group): About $2 \mathrm{~kg}$ of shrimp was stored with sufficient ice. The melting temperature of ice was measured as $0-2^{\circ} \mathrm{C}$ by a thermocouple thermometer. Sample B: About $2 \mathrm{~kg}$ of shrimp was stored with a mixture of crushed ice and $3 \%$ $\mathrm{NaCl}(\mathrm{w} / \mathrm{w})$. The melting temperature of ice was $-2 \sim-6^{\circ} \mathrm{C}$. Sample C: About $2 \mathrm{~kg}$ of shrimp was stored a with mixture of crushed ice and $7 \%$ $\mathrm{NaCl}$. The melting temperature of ice was $-3 \sim$ $-8^{\circ} \mathrm{C}$. The ratio of the quantity of shrimp to that of ice was $1: 2$ in this study. At definite time intervals, samples were removed and subjected to the quality assays.

Effect of Mixtures of Crushed Ice and Chemicals (K-sorbate, Na-polyphosphate, Na-pyrophosphate) on the Storage Life of Shrimp

To understand the effect of the addition of $\mathrm{K}$ sorbate, $\mathrm{Na}$-polyphosphate and $\mathrm{Na}$-pyrophosphate to crushed ice on the storage life of shrimp, samples were divided into 3 groups. Sample A (control); stored with sufficient amount of crushed ice. Sample D: stored with a mixture of crushed ice and $0.1 \% \mathrm{~K}$-sorbate (w/w). Sample E: stored with a mixture of crushed ice, $0.1 \% \mathrm{~K}$-sorbate,

* Department of Marine Food Science, National Taiwan College of Marine Science \& Technology, Keelung, Taiwan 200, R.O.C. 
$0.05 \%$ Na-polyphosphate and Na-pyrophosphate. At definite time intervals, samples were removed and subjected to the quality assays.

Effect of the Combination Use of Curshed Ice, 3\% $\mathrm{NaCl}, K$-sorbate, Na-polyphosphate and $\mathrm{Na}$ pyrophosphate on the Storage Life of Shrimp

Shrimp samples were separated into 3 groups. Sample A (control): stored with sufficient crushed ice. Sample F: stored with a mixture of crushed ice, $3 \% \mathrm{NaCl}$ and $0.1 \% \mathrm{~K}$-sorbate. Sample G: stored with a mixture of crushed ice, $3 \% \mathrm{NaCl}$, $0.1 \% \mathrm{~K}$-sorbate, $0.05 \% \mathrm{Na}$-poiyphosphate and $0.05 \%$ pyrophosphate. At definite time intervals, samples were removed and subjected to the quality assays.

\section{Quality Assay}

The quality of shrimp during storage was assessed by measuring the volatile base nitrogen (VB-N), extractive-nitrogen (AA-N), inosine- $5^{\prime}$ monophosphate (IMP) ratio, indole, microbial growth and sensory evaluation. Measurements were monitored with pooling $500 \mathrm{~g}$ shrimp together (size: $200-300$ shrimps $/ \mathrm{kg}$ ). Three samples from each group were taken for quality assays.

\section{Volatile Base Nitrogen}

The VB-N was extracted and determined according to the method of Akiba et al. ${ }^{23)} \quad$ To about $5 \mathrm{~g}$ of shrimp meat, $25 \mathrm{~m} l$ of $6 \%$ trichloroacetic acid (TCA) was added and homogenized. Centrifugation was performed at $3000 \mathrm{rpm}$ for $10 \mathrm{~min}$ at room temperature. The precipitates were washed with $20 \mathrm{~m} l$ of $6 \%$ TCA solution. Finally, the collected supernatants were filtered with a filter paper (Toyo No. 5B) and made to $50 \mathrm{~m} l$ with $6 \%$ TCA solution. VB-N was determined by Conway's microdiffusion method.

\section{Extractive Nitrogen}

The extracts were prepared by homogenizing shrimp meat at a ratio of $20 \mathrm{~g}$ shrimp meat to $50 \mathrm{ml}$ of $7 \%$ TCA solution using a Polytron homogenizer (Kinematica GmbH, Switzerland). The mixture was centrifuged and filtered with a filter paper (Toyo No. 5B). The precipitates were washed with $30 \mathrm{ml}$ of $7 \%$ TCA solution, centrifuged, and filtered again. The collected supernatants was made to $100 \mathrm{ml}$ and subjected to the micro-Kjeldahl distillation analyses. The content of nitrogen, being essentially amino acidnitrogen $(A A-N)$ was expressed as millimoles of nitrogen per $100 \mathrm{~g}$ of shrimp meat.

\section{Inosine Monophosphate Ratio}

The extraction of nucleotides and determination of inosine monophosphate (IMP) ratio were monitored as follows: to $2 \mathrm{~g}$ of shrimp meat, 6 $\mathrm{m} l$ of $4 \%$ chilled perchloric acid (PCA) solution was added and homogenized. Centrifugation was performed at $3000 \mathrm{rpm}$ for $10 \mathrm{~min}$. The precipitates were washed twice with $5 \mathrm{~m} l$ of $4 \%$ chilled PCA solution. The collected supernatants were filtered with a filter paper (Toyo No. 5B). After adjusting the pH of filtrates to 6.5 with $10 \mathrm{~N}$ and $1.0 \mathrm{~N} \mathrm{KOH}$ solution, the filtrates were filtered again and the volume was made up to $20 \mathrm{~m} l$ using neutralized PCA solution ( $\mathrm{pH} 6.5$ ).

The nucleotides were eluted with three grading solvents ${ }^{24)} ; 5 \mathrm{mM} \mathrm{NH}_{4} \mathrm{H}_{2} \mathrm{PO}_{4} /$ acetonitrile (13:87), $5 \mathrm{mM} \mathrm{NH} \mathrm{NH}_{2} \mathrm{PO}_{4}$ and $0.75 \mathrm{M} \mathrm{NH}_{4} \mathrm{H}_{2} \mathrm{PO}_{4}$ using a high pressure liquid chromatography (HPLC, instrument: Varian 5020; AX-10, $0.4 \times 30 \mathrm{~cm}$ ). The areas of each peak were automatically computed. The quantity of the neucleotides were calculated by comparing the peaks of sample with those of standard. The IMP ratio was expressed as a ratio of the quantity of IMP to the sum of IMP, inosine $(\mathrm{Hx})$ and hypoxanthine (HxR).

\section{Indole}

The indole content was examined according to the method suggested by $\mathrm{AOAC}^{25)}$ and expressed as micrograms of indole in $100 \mathrm{~g}$ of shrimp meat.

\section{Microbiological Assessment}

To determine the potential bacteriostatic effect of the modified ice storage on microflora of shrimp, $25 \mathrm{~g}$ of whole shrimp was removed aseptically and homogenized with $225 \mathrm{~m} l$ of $0.1 \%$ sterile peptone water (Trypticase peptone, BBL). Several dilutions were made in sterile peptone water and duplicate plates were poured using plate agar (Difco). Plates were incubated at $37^{\circ} \mathrm{C}$ for 2 days prior to counting. ${ }^{28)}$

\section{Sensory Evaluation}

Sensory evaluation was done by 9 trained panelists on a 9-point hedonic scale.

\section{Statistic Analysis}

Duncan's Multiple Range Test was used for statistical analysis.

\section{Results and Discussion}

Effect of Mixture of Crushed Ice and Salt on the Storage Life of Shrimp

Table 1 shows the changes in VB-N, AA-N, and 
Table 1. Changes in volatile base nitrogen (VB-N), extractive nitrogen (AA-N) and VB-N/AA-N ratio of the shrimp during storage in the mixtures of crushed ice and $3 \%$ or $7 \%$ salt

\begin{tabular}{|c|c|c|c|c|c|c|c|c|c|}
\hline \multirow[t]{2}{*}{$\begin{array}{l}\text { Storage } \\
\text { (day) }\end{array}$} & \multicolumn{3}{|c|}{$\begin{array}{c}\text { VB-N } \\
(\mathrm{mg} / 100 \mathrm{~g})\end{array}$} & \multicolumn{3}{|c|}{$\underset{(\mathrm{mmol} / 100 \mathrm{~g})}{\text { AA-N }}$} & \multicolumn{3}{|c|}{ VB-N/AA-N } \\
\hline & $A^{*}$ & $\mathrm{~B}^{*}$ & $C^{*}$ & A & B & $\mathrm{C}$ & A & B & $\mathrm{C}$ \\
\hline 0 & 15.3 & 15.3 & 15.3 & 25.3 & 25.3 & 25.3 & $0.60 \mathrm{a}^{* *}$ & $0.60 \mathrm{a}$ & $0.60 a$ \\
\hline 4 & 9.0 & 10.4 & 9.8 & 12.0 & 15.5 & 14.8 & $0.75 \mathrm{a}$ & $0.67 b$ & $0.66 \mathrm{~b}$ \\
\hline 7 & 20.4 & 8.8 & 5.5 & 5.3 & 6.0 & 3.8 & $3.71 \mathrm{a}$ & $1.47 \mathrm{~b}$ & $1.45 b$ \\
\hline 11 & 22.3 & 10.0 & 6.8 & 4.5 & 5.8 & 5.0 & $4.96 \mathrm{a}$ & $1.72 \mathrm{~b}$ & $1.36 \mathrm{c}$ \\
\hline 13 & 28.0 & 10.5 & 6.0 & 4.8 & 3.6 & 2.0 & $5.83 a$ & $2.92 \mathrm{~b}$ & $3.00 \mathrm{~b}$ \\
\hline 15 & 26.8 & 13.3 & 5.4 & 4.3 & 3.6 & 1.3 & $6.23 a$ & $3.69 \mathrm{~b}$ & $3.00 \mathrm{c}$ \\
\hline $\begin{array}{l}\text { A: } \\
\text { B: } \\
\text { C: }\end{array}$ & $\begin{array}{l}\text { control } \\
\text { stored in } \\
\text { stored in }\end{array}$ & ure of & ice a & art (h) & & & & & \\
\hline
\end{tabular}

Table 2. The sensory quality* of the shrimp stored in the mixtures of crushed ice and $3 \%$ or $7 \%$ salt

\begin{tabular}{clcl}
\hline \multirow{2}{*}{$\begin{array}{c}\text { Storage } \\
\text { (day) }\end{array}$} & \multicolumn{3}{c}{ Treatment } \\
\cline { 2 - 4 } & $\mathrm{A}^{* *}$ & $\mathrm{~B}^{* *}$ & $\mathrm{C}^{* *}$ \\
\hline 0 & $8.5 \mathrm{a}^{* * *}$ & $8.5 \mathrm{a}$ & $8.5 \mathrm{a}$ \\
7 & $4.7 \mathrm{~b}$ & $7.4 \mathrm{a}$ & $6.7 \mathrm{a}$ \\
11 & $3.4 \mathrm{~b}$ & $6.6 \mathrm{a}$ & $6.3 \mathrm{a}$ \\
13 & $2.4 \mathrm{~b}$ & $6.5 \mathrm{a}$ & $6.1 \mathrm{a}$ \\
15 & $2.1 \mathrm{c}$ & $5.9 \mathrm{a}$ & $4.1 \mathrm{~b}$ \\
\hline
\end{tabular}

* The 9-point hedonic scale was employed for evaluating the sensory quality (9: like extremely; 5: neither like nor dislike; 1 : dislike extremely).

** A: stored in crushed ice; B: stored in a mixture of crushed ice and $3 \% \mathrm{NaCl} ; \mathrm{C}$; stored in a mixture of crushed ice and $7 \% \mathrm{NaCl}$.

*** see Table 1.

VB-N/AA-N of the shrimp muscle during storage. Values in the talbe were the means of 3 determinations for each evaluation date. VB-N in sample $A$ (control sample) decreased slightly during 4 days storage. However, it increased rapidly during prolonged storage. The VB- $\mathrm{N}$ increased from an initial level of $15.3 \mathrm{mg} / 100 \mathrm{~g}$ in fresh sample to $26.8 \mathrm{mg} / 100 \mathrm{~g}$ after 15 days storage. Gradual decrease in VB-N of the samples stored in mixture of crushed ice and $3 \%$ salt, and in mixture of crushed ice and $7 \%$ salt was observed during 15 days storage $(\mathrm{P}<0.01)$.

The extractive-nitrogen (AA-N) in all samples decreased rapidly during 7 days storage, but there was no significant changes during the extended period of storage. In this study, although the samples $\mathbf{B}$ and $\mathbf{C}$ were not acceptable after 15 days storage (Table 2), they still showed a consistently low VB-N level. In addition, the AA-N in all samples decreased during early storage and no significant difference among control and treated samples was observed. These data indicated that neither VB-N nor AA-N itself can be a good index for the freshness of iced shrimp. It is probably because the VB-N and AA-N are easily lost with the melting ice water during early storage. $4,17,18,27,28)$ However, it has been reported that the VB-N in shrimp meat increased rapidly after extended ice storage due to the microbial growth. $^{18,28)}$. Thus, some studies ${ }^{18,30,31)}$ suggested that the VB-N/AA-N ratio was more effective for evaluating the quality of shrimp than either VB-N or AA-N alone. As shown in Table 1, a rapid and consistent increase in VB-N/AA-N ratio was noted in control sample after 7 days storage, that of treated samples, however, increased slowly during 15 days storage and from an initial level of 0.6 reached a level of 3.69 in sample $B$ and 3.0 in sample $\mathrm{C}$.

The aerobic plate count of control samples increased from an initial level of $6.3 \times 10^{4} \mathrm{cell} / \mathrm{g}$ to $1.6 \times 10^{8} \mathrm{cell} / \mathrm{g}$ after 7 days storage and increased sharply during extended period of storage (Fig. 1). No significant increase in microbial growth in treated samples was observed even after 11 days storage $(P<0.01)$. The microbial growth of shrimp was effectively delayed by storage in the mixture of crushed ice and $3 \% \mathrm{NaCl}$, and in the mixture of crushed ice and $7 \% \mathrm{NaCl}$ during 11 days of storage, in contrast to that of control sample. The incipience of microbial growth in control sample, samples $B$ and $C$ was considered to be after 4, 11 and 11 days storage, respectively.

Data obtained from the measurement of indole content was variable and appeared to have little relation to the quality of shrimp during ice storage (Fig. 2). The sensory score is presented in Table 2. Values filled are means of 9-judgements evalua- 


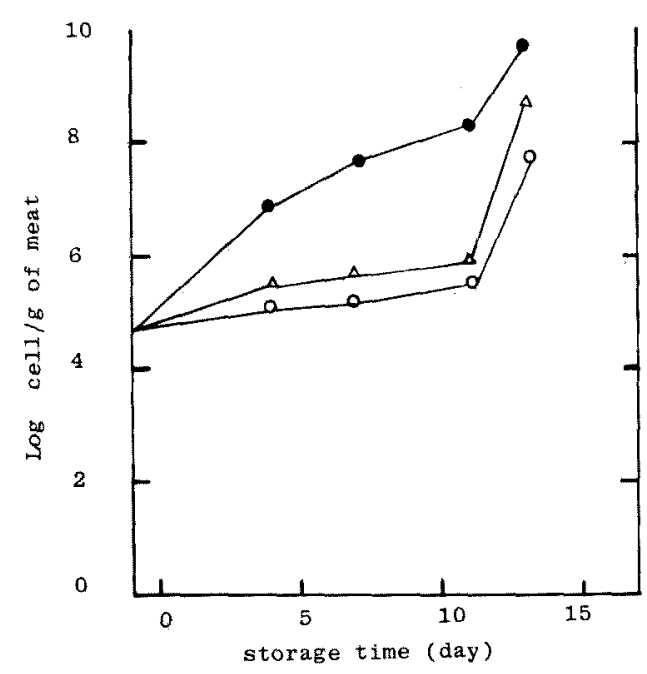

Fig. 1. Changes in bacterial counts of shrimp meat stored in the mixtures of crushed ice and 3 or $7 \%$ salt per ice (๑: sample $A, O$ : sample $B, \triangle$ : sample $\mathrm{C}$, refer to the footnote in Table 1).

tions based on a 9-point hedonic scale. According to the taste panel, the control sample was almost unacceptable after 7 days storage. However, samples $B$ and $C$ were still acceptable even after 15 and 13 days storage, respectively. The ratio of VB-N/AA-N (Table 1) showed a good correlation with sensory evaluation in this experiment. The iced shrimp was almost not accepted by most of panelists, when the VB-N/AA-N ratio reached around 4. This might be due to the rapid increase in VB-N produced by microbia at the advanced spoilage stage.

The storage life of shrimp samples stored in a mixture of crushed ice and $3 \% \mathrm{NaCl}$, and in a mixture of crushed ice and $7 \% \mathrm{NaCl}$ was extended from 7 days to 15 and 13 days, respectively. According to a study on ice preservation of fish and shellfish, ${ }^{24}$ the ash content of mackerel muscle stored in a mixture of crushed ice and $3 \% \mathrm{NaCl}$ retained almost at a constant level, whereas, that of shrimps stored in a mixture of crushed ice and $7 \% \mathrm{NaCl}$ increased rapidly during early stage of storage and slowly at the prolonged storage. This might be because the fish lives in the sea water of which salt concentration is about $3 \%$, and the fish muscle has iso-osmosis with $3 \% \mathrm{NaCl}$ water. However, salt penetration will occur in shrimps stored in the mixture of crushed ice and $7 \% \mathrm{NaCl}$ due to the difference in osmotic pressure between the melting ice water and membrane of the muscle cell. This cause the shrimp to lose its prime

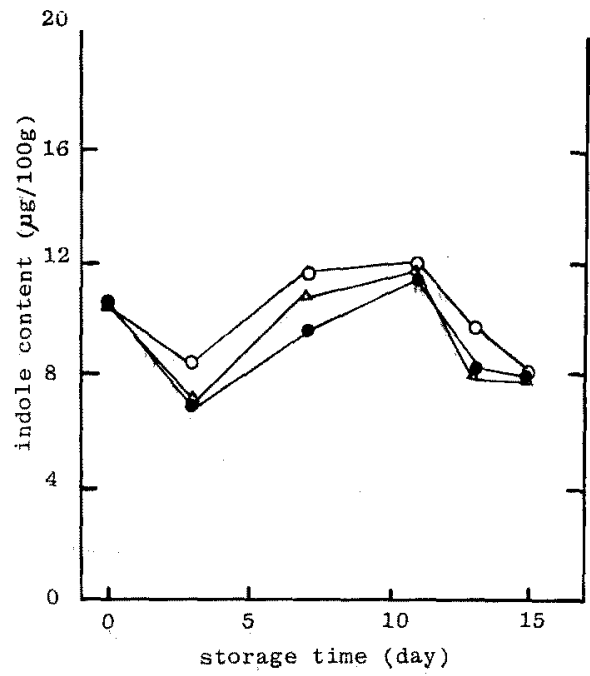

Fig. 2. Changes in indole content of shrimp meat stored in the mixtures of crushed ice and 3 or $7 \%$ salt (•: sample A, O: sample B, $\triangle$ : sample C, refer to the footnote in Table 1).

flavor. Accordingly, it is suggested that the mixture of crushed ice and $3 \% \mathrm{NaCl}$ is proper for preserving shrimp.

\section{Effect of Mixture of Crushed Ice and Chemicals on} the Storage Life of Shrimp

Dipping treatment of $\mathrm{K}$-sorbate solution showed a marked inhibition of microbial growth of poultry and fish, ${ }^{32-35)}$ and storage with sea water ice containing $0.05 \% \mathrm{~K}$-sorbate, $0.05 \% \mathrm{Na}$-polyphosphate and $0.05 \%$ Na-pyrophosphate extended the storage life of semi-dressed flounder fish from 10 days to 26 days. ${ }^{36}$ The polyphosphates were reported to have effects on reducing the drip loss of frozen fish and inhibiting the autolysis of fish muscle. ${ }^{37-30)}$ In this experiment, an attempt to investigate the effect of these chemicals mixed with crushed ice on extending the storage life of shrimp was made.

As shown in Table 3, the VB-N increased rapidly in control samples (A) from the initial leyel of 12.0 $\mathrm{mg} / 100 \mathrm{~g}$ to $21.4 \mathrm{mg} / 100 \mathrm{~g}$ after 4 days storage, and to $32.6 \mathrm{mg} / 100 \mathrm{~g}$ after 11 days storage. However, that of shrimp stored in crushed ice containing the chemicals $(\mathrm{D}, \mathrm{E})$ was kept below 20 $\mathrm{mg} / 100 \mathrm{~g}$ during 7 days storage, which was the upper limit value for fresh fish and shellfish permitted by FDA in Taiwan. The AA-N of all the samples decreased very quickly during 11 days storage and no significant difference among control and treated samples was observed within 11 days 
Table 3. Changes in VB-N, AA-N and VB-N/AA-N ratio of the shrimp during storage in the mixtures of crushed ice and K-storbate, Na-polyphosphate and Na-pyrophosphate

\begin{tabular}{|c|c|c|c|c|c|c|c|c|c|}
\hline \multirow[t]{2}{*}{$\begin{array}{c}\text { Storage } \\
\text { (day) }\end{array}$} & \multicolumn{3}{|c|}{$\begin{array}{c}\text { VB-N } \\
(\mathrm{mg} / 100 \mathrm{~g})\end{array}$} & \multicolumn{3}{|c|}{$\begin{array}{c}\mathrm{AA}-\mathrm{N} \\
(\mathrm{mmol} / 100 \mathrm{~g})\end{array}$} & \multicolumn{3}{|c|}{ VB-N/AA-N } \\
\hline & $A^{*}$ & $\mathrm{D}^{*}$ & $\mathrm{E}^{*}$ & A & $\mathrm{D}$ & $\mathrm{E}$ & A & $\mathrm{D}$ & $E$ \\
\hline 0 & 12.0 & 12.0 & 12.0 & 25.3 & 25.3 & 25.3 & $0.47 a^{* *}$ & $0.47 a$ & $0.47 \mathrm{a}$ \\
\hline 4 & 21.4 & 17.5 & 15.3 & 15.8 & 17.5 & 14.9 & $1.35 \mathrm{a}$ & $1.00 \mathrm{~b}$ & $1.03 b$ \\
\hline 7 & 22.0 & 15.0 & 13.9 & 5.8 & 11.5 & 10.9 & $3.79 a$ & $1.30 \mathrm{~b}$ & $1.28 \mathrm{~b}$ \\
\hline 9 & 22.5 & 21.3 & 21.9 & 4.3 & 5.8 & 5.8 & $5.23 a$ & $3.67 \mathrm{~b}$ & $3.78 \mathrm{~b}$ \\
\hline 11 & 32.6 & 25.0 & 22.5 & 4.3 & 5.3 & 4.6 & $7.58 \mathrm{a}$ & $4.72 b$ & $4.89 \mathrm{~b}$ \\
\hline
\end{tabular}

* A: stored with sufficient crushed ice (control).

D: stored in a mixture of crushed ice and $0.1 \% \mathrm{~K}$-sorbate.

$\mathrm{E}:$ stored in a mixture of crushed ice and $0.1 \% \mathrm{~K}$-sorbate and $0.1 \%$ phosphate ( $50 \%$ polyphosphate and $50 \%$ pyrophosphate). ** see Table 1.

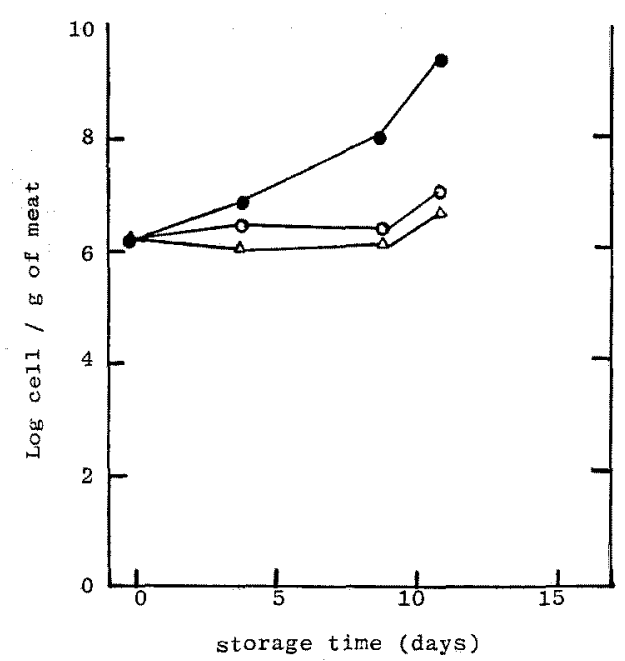

Fig. 3. Changes in bacterial counts of shrimp meat stored in the mixtures of crushed ice and $\mathrm{K}$ sorbate, Na-polyphosphate and Na-pyrophosphate ( : sample A, O: sample $\mathrm{D}, \triangle$ : sample $\mathrm{E}$, refer to the footnote in Table 3).

storage. The VB-N/AA-N ratio of the control samples increased slowly during the first 4 days storage but rapidly thereafter, while that of sample $\mathrm{D}$ and $\mathrm{E}$ increased slowly during the first 7 days storage, but sharply thereafter. The VB-N/AA-N ratio in both samples $D$ and $E$ reached around 4 after 9 days storage, while that of the control sample reached 4 after 7 days storage.

Combined use of crushed ice and $\mathrm{K}$-sorbate showed excellent effects on inhibiting the microbial growth in shrimp (Fig. 3). No significant changes in aerobic plate count in treated samples was observed, while that of control samples increased from $1.1 \times 10^{8} \mathrm{cell} / \mathrm{g}$ of meat of $1.6 \times 10^{8} \mathrm{cell} / \mathrm{g}$ of meat after 9 days storage. It was also found that

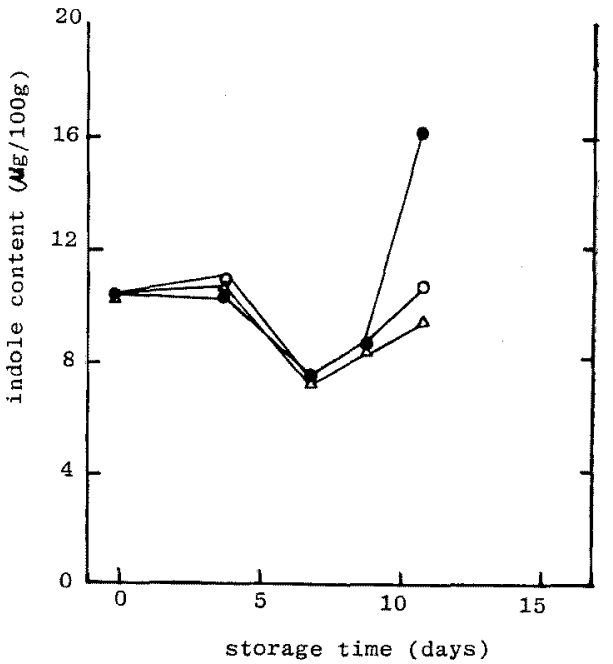

Fig. 4. Changes in the indole content of shrimp meat stored in the mixtures of crushed ice and $\mathrm{K}$ sorbate, Na-polyphosphate and Na-pyrophosphate ( : sample A, O: sample $D, \Delta$ : sample $E$, refer to the footnote in Table 3).

the indole content had little relation to the sensory quality of shrimp (Fig. 4). It is recoginized that the development of indole was very slow at low temperature but rapid during exposure to high temperature. In addition, the accumulation of indole is mainly from the degradation of tryptophan, which easily lost with the melting ice. The indole content of shrimp is, therefore, variable and showed no relation to the sensory quality during ice storage.

Data from sensory evaluation are presentde in Table 4. The control sample was not accepted by the taste panel after 7 days storage, while the treated samples were still acceptable even after 9 days storage, with sample $E$ being better than 
Table 4. The sensory quality* of the shrimp stored in the mixtures of crushed ice and K-sorbate, Napolyphosphate and $\mathrm{Na}$-pyrophosphate

\begin{tabular}{clll}
\hline \multirow{2}{*}{$\begin{array}{c}\text { Storage } \\
\text { (day) }\end{array}$} & \multicolumn{3}{c}{ Treatment } \\
\cline { 2 - 4 } & $\mathrm{A}^{* *}$ & $\mathrm{D}^{* *}$ & $\mathrm{E}^{* *}$ \\
\hline 0 & $7.7 \mathrm{a}^{* * *}$ & $7.7 \mathrm{a}$ & $7.7 \mathrm{a}$ \\
4 & $6.7 \mathrm{a}$ & $7.3 \mathrm{a}$ & $6.8 \mathrm{a}$ \\
7 & $4.9 \mathrm{~b}$ & $5.8 \mathrm{a}$ & $6.2 \mathrm{a}$ \\
9 & $3.9 \mathrm{~b}$ & $5.3 \mathrm{a}$ & $5.6 \mathrm{a}$ \\
11 & $2.0 \mathrm{~b}$ & $3.3 \mathrm{a}$ & $3.6 \mathrm{a}$ \\
\hline
\end{tabular}

* see Table 2 .

** A: stored in crushed ice; $D$ : stored in a mixture of crushed ice and $0.1 \% \mathrm{~K}$-sorbate; E: stored in a mixture crushed ice, $0.1 \%$ sorbate, $0.05 \%$ Na-polyphosphate and $0.05 \%$ Na-pyrophosphate.

*** see Table 1.

sample $\mathrm{D}$.

From this experiment, the storage with crushed ice and $0.1 \% \mathrm{~K}$-sorbate, or with crushed ice and $0.1 \% \mathrm{~K}$-sorbate, $0.05 \% \mathrm{Na}$-polyphosphate and $0.05 \% \mathrm{Na}$-pyrophosphate showed excellent effect on inhibiting the microbial growth and extending the storage life of shrimp.

Effect of the Combination of Crushed Ice, $3 \% \mathrm{NaCl}$ and Chemicals on the Storage Life of Shrimp

Changes in VB-N, AA-N and VB-N/AA-N ratio of shrimp samples during ice storage with the combination of crushed ice, $3 \% \mathrm{NaCl}$ and other chemicals are shown in Table 5. The VB-N increased slowly in sample $F$ and $G$, from the initial level of $11.3 \mathrm{mg} / 100 \mathrm{~g}$ to 19.8 and 18.0 $\mathrm{mg} / 100 \mathrm{~g}$, respectively, after 17 days. However, the VB-N of sample A (control) increased rapidly and consistently with the extended storage, from 11.3 to $34.1 \mathrm{mg} / 100 \mathrm{~g}$ of meat after 17 days storage. The VB-N/AA-N ratio of control sample reached

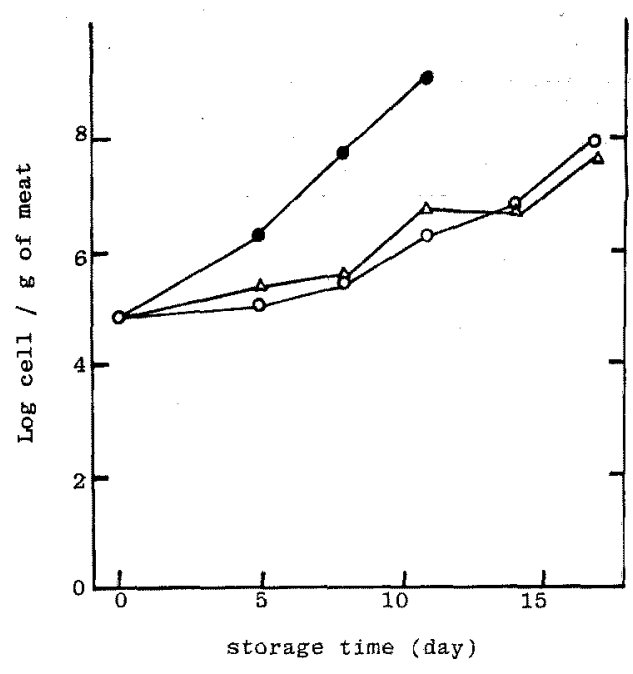

Fig. 5. Changes in bacterial counts of shrimp meat stored in the crushed ice containing $3 \%$ salt and K-sorbate or Na-polyphosphate and Na-pyrophosphate ( : sample A, O: sample F, $\Delta$ : sample $\mathrm{G}$, refer to the footnote in Table 5).

the value of 4 after 8 days storage, and increased rapidly during the prolonged storage. However, that of samples $F$ and $G$ was still below 4 even after 17 days storage.

The aerobic plate count of shrimp stored with crushed ice containing $3 \% \mathrm{NaCl}$ and chemicals $(F, G)$ increased from the initial level of $5.6 \times 10^{4}$ cell $/ \mathrm{g}$ to $1.6 \times 10^{8}$ and $6.3 \times 10^{7} \mathrm{cell} / \mathrm{g}$, in sample $F$ and $G$, respectively after 17 days storage, while that of control sample was $1.3 \times 10^{9} \mathrm{cell} / \mathrm{g}$ after 11 days storage (Fig. 5). According to these data, the incipience of microbial growth in samples $A$ (control), $\mathrm{F}$, and $\mathrm{G}$ was considered to be at 5 th,

Table 5. Changes in VB-N, AA-N and VB-N/AA-N ratio of the shrimp during storage in the crushed ice containing $3 \%$ salt and $\mathrm{K}$-sorbate or Na-polyphosphate and $\mathrm{Na}$-pyrophosphate besides

\begin{tabular}{|c|c|c|c|c|c|c|c|c|c|}
\hline \multirow[t]{2}{*}{$\begin{array}{l}\text { Storage } \\
\text { (day) }\end{array}$} & \multicolumn{3}{|c|}{$\begin{array}{c}\text { VB-N } \\
(\mathrm{mg} / 100 \mathrm{~g})\end{array}$} & \multicolumn{3}{|c|}{$\begin{array}{c}\text { AA-N } \\
(\mathrm{mmol} / 100 \mathrm{~g})\end{array}$} & \multicolumn{3}{|c|}{ VB-N/AA-N } \\
\hline & $A^{*}$ & $F^{*}$ & $\mathrm{G}^{*}$ & A & $\mathrm{F}$ & $\mathrm{G}$ & A & $\mathrm{F}$ & $\mathbf{G}$ \\
\hline 0 & 11.3 & 11.3 & 11.3 & 31.1 & 31.1 & 31.1 & $0.36 \mathrm{a}^{* *}$ & $0.36 \mathrm{a}$ & $0.36 a$ \\
\hline 5 & 18.8 & 13.3 & 12.8 & 16.8 & 17.0 & 18.6 & $1.12 a$ & $0.78 \mathrm{~b}$ & $0.66 c$ \\
\hline 8 & 20.5 & 14.0 & 12.3 & 6.3 & 9.8 & 13.0 & $3.25 \mathrm{a}$ & $1.43 \mathrm{~b}$ & $0.95 c$ \\
\hline 11 & 23.8 & 14.5 & 11.9 & 4.5 & 5.8 & 6.6 & $5.29 a$ & $2.50 \mathrm{~b}$ & $1.80 \mathrm{c}$ \\
\hline 14 & 29.4 & 16.3 & 14.1 & 3.8 & 6.0 & 5.0 & $7.74 a$ & $2.72 b$ & $2.82 \mathrm{~b}$ \\
\hline 17 & 34.1 & 19.8 & 18.0 & 3.8 & 6.0 & 5.1 & $8.97 a$ & $3.30 \mathrm{c}$ & $3.60 \mathrm{~b}$ \\
\hline
\end{tabular}

* A; stored with sufficient ice (control).

$\mathrm{F}$ : stored in a mixture of crushed ice, $3 \% \mathrm{NaCl}$ and $0.1 \% \mathrm{~K}$-sorbate.

G: stored in a mixture of crushed ice, $3 \% \mathrm{NaCl}, 0.1 \% \mathrm{~K}$-sorbate, $0.05 \%$ Na-polyphosphate and $0.05 \%$ Na-pyrophosphate.

** see Table 1 . 

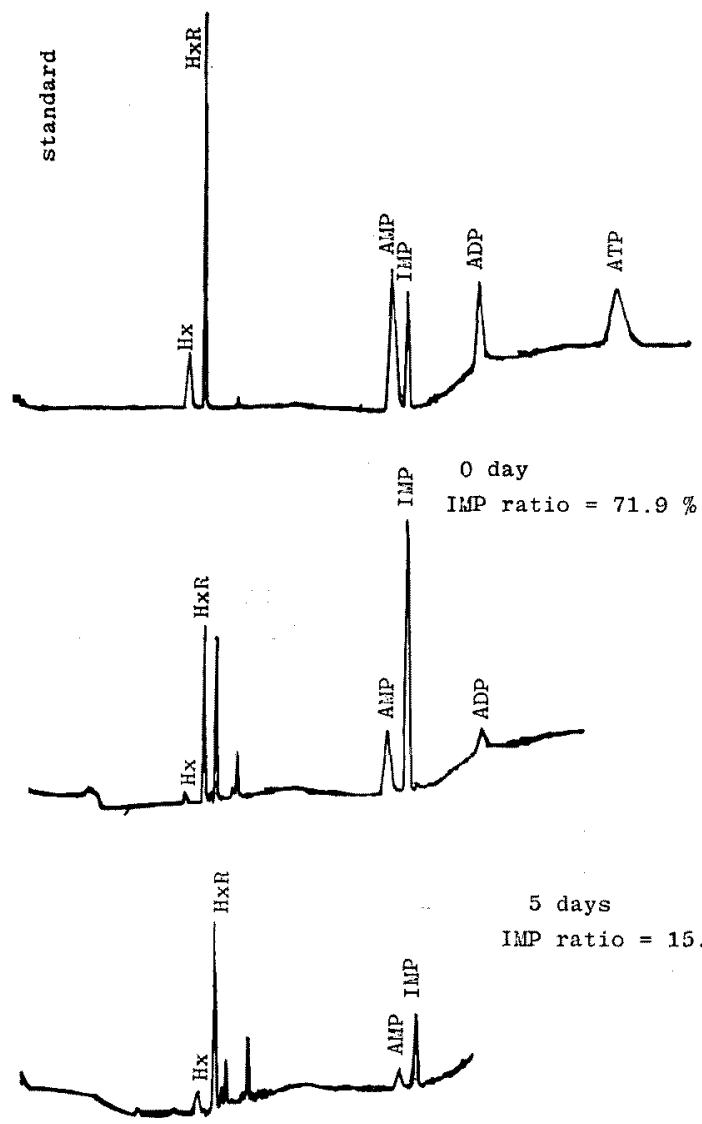

5 days

$I M P$ ratio $=15.0 \%$

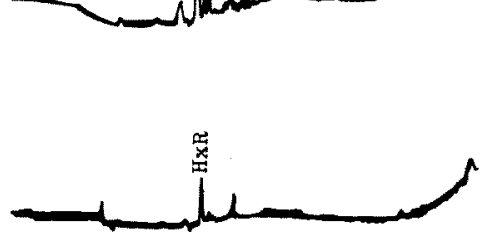

8 days

IMP ratio $=0 \%$

Fig. 6. Change in IMP ratio $\left(\frac{\text { IMP }}{H x+H x R+I M P}\right)$ during ice storage.

(Hx: hypoxanthine; HxR: inosine; IMP: inosine monophosphate; AMP: adenosine monophosphate; ADP: adenosine diphosphate; ATP: adenosine triphosphate. The ATP and its relative compounds were eluted using High Pressure Liquid Chromatography. Instrument: Varian 5020; Colum: AX-10; Solvents: A). $5 \mathrm{mM} \mathrm{NH}_{4} \mathrm{H}_{2} \mathrm{PO}_{4}$ /acetonitrile (13: 87), B). $5 \mathrm{mM} \mathrm{NH}_{4} \mathrm{H}_{2} \mathrm{PO}_{4}$, C). $0.75 \mathrm{M} \mathrm{NH}_{4} \mathrm{H}_{2} \mathrm{PO}_{4}$ ).

11th and 11th day of storage and entered the advanced spoilage stage after 8,17 , and 17 days storage, respectively.

The accumulation of hypoxanthine and IMP content were reported to be a good index for the assessment of the quality of shrimp. ${ }^{40)}$ In this study, changes in nucleotide profile during storage were determined by using a high performance liquid chromatography (HPLC). As shown in
Figs. 6, 7, and 8, the IMP ratio of fresh shrimp was very high $71.9 \%$. However, the IMP ratio of control sample was $1.50 \%$ and $0 \%$ after 5 and 8 days storage, respectively. The IMP ratio of samples $F$ retained a high value during 5 days storage and was $1.25 \%$ even after 15 days storage (Fig. 7). That of sample $G$ was $49.2,24.4$, and $15.0 \%$ after 5,11 , and 15 days of storage, respectively (Fig. 8). From these data, it is obvious that 


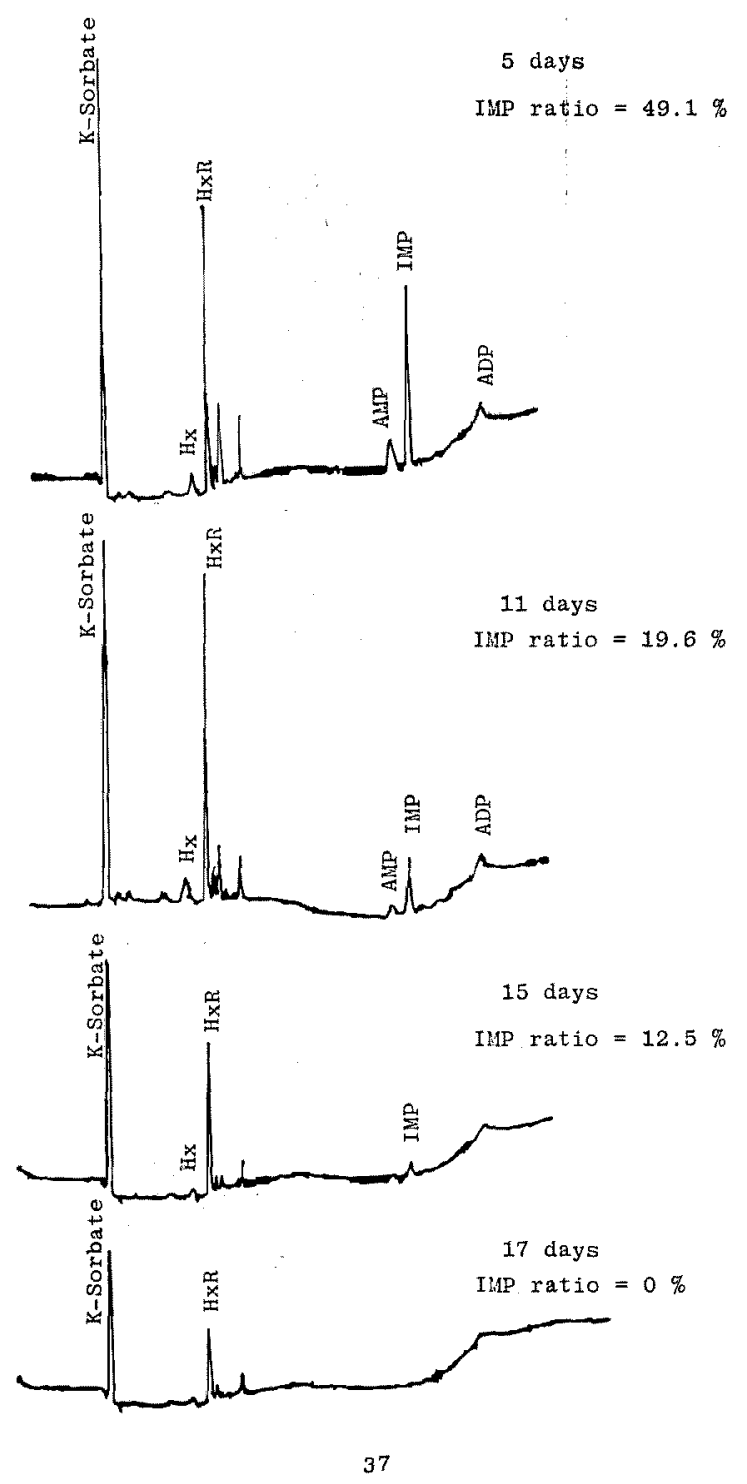

Fig. 7. Change in IMP ratio of shrimp meat during storage in a mixture of crushed ice, $3 \% \mathrm{NaCl}$ and $0.1 \% \mathrm{~K}$-sorbate.

storage in a mixture of crushed ice, $3 \% \mathrm{NaCl}$, and $0.1 \% \mathrm{~K}$-sorbate, and in a mixture of crushed ice, $3 \% \mathrm{NaCl}, 0.1 \% \mathrm{~K}$-sorbate, $0.05 \% \mathrm{Na}$-polyphosphate, and $0.05 \%$ Na-pyrophosphate, were very helpful for the retention of IMP of shrimp.

Table 6 illustrates the sensory quality of shrimp during storage. Samples $F$ and $G$ were still acceptable after 14 and 17 days of storage, respectively, while the control sample was not acceptable after 8 days of storage.
It is clear that storage in the mixture of crushed ice, $3 \% \mathrm{NaCl}$, and $0.1 \% \mathrm{~K}$-sorbate, or the mixture of crushed ice, $3 \% \mathrm{NaCl}, 0.1 \% \mathrm{~K}$-sorbate, $0.05 \%$ $\mathrm{Na}$-polyphosphate, and $0.05 \% \mathrm{Na}$-pyrophosphate, were effectively extended the shelf-life of shrimp. The reasons might be: a) the chilling rate is higher due to the greater difference in temperature between shrimp and chilling mixture, b) lower storage temperature $\left(-2 \sim-6^{\circ} \mathrm{C}\right)$, c) inhibitory effects of $\mathrm{K}$-sorbate on microbial growth during storage, 
章

5 days
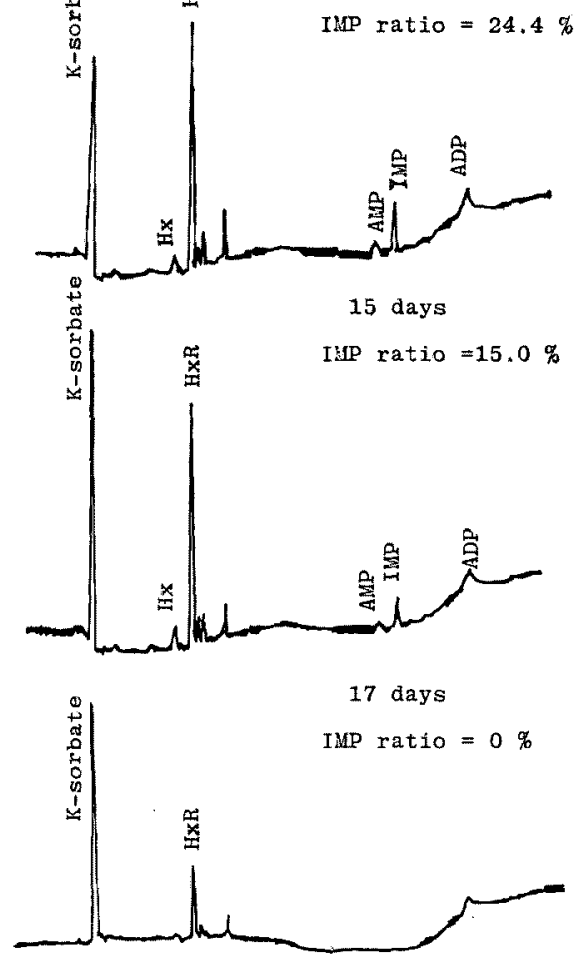

39

Fig. 8. Change in IMP ratio of shrimp meat during storage in a mixture of crushed ice, $3 \% \mathrm{NaCl}$, $0.1 \% \mathrm{~K}$-sorbate, $0.05 \% \mathrm{Na}$-polyphosphate and $0.05 \% \mathrm{Na}$-pyrophosphate.

and d) effect of polyphosphate on delaying the rate of autolysis of shrimp meat.

\section{References}

1) E. A. Fieger: Food Tech., 4, 409-411 (1950).

2) M. E. Bailey, E. A. Fieger, and A. F. Novak: Food Res., 21, 611-619 (1956).

3) J. A. Alford: Food Tech., 6, 217-219 (1952).

4) B. A. Fieger and J. J. Friloux: Food Tech, 8, 35-38 (1954).
Table 6. The sensory quality* of the shrimp stored in the crushed ice containing $3 \%$ salt and $K$ sorbate or Na-polyphosphate and Na-pyrophosphate besides

\begin{tabular}{clll}
\hline \multirow{2}{*}{$\begin{array}{c}\text { Storage } \\
\text { (day) }\end{array}$} & \multicolumn{3}{c}{ Treatment } \\
\cline { 2 - 4 } & $\mathrm{A}^{* *}$ & $\mathrm{~F}^{* *}$ & $\mathrm{G}^{* *}$ \\
\hline 0 & $7.5 \mathrm{a}^{* * *}$ & $7.5 \mathrm{a}$ & $7.5 \mathrm{a}$ \\
5 & $6.2 \mathrm{~b}$ & $7.6 \mathrm{a}$ & $7.5 \mathrm{a}$ \\
8 & $5.0 \mathrm{~b}$ & $7.2 \mathrm{a}$ & $7.4 \mathrm{a}$ \\
11 & $3.5 \mathrm{~b}$ & $6.3 \mathrm{a}$ & $6.6 \mathrm{a}$ \\
14 & - & $5.5 \mathrm{a}$ & $6.0 \mathrm{a}$ \\
17 & - & $4.9 \mathrm{a}$ & $5.2 \mathrm{a}$ \\
\hline
\end{tabular}

* see Table 2 .

* A: stored in crushed ice; $F$ : stored in a mixture of crushed ice, $3 \% \mathrm{NaCl}$ and $0.1 \% \mathrm{~K}$-sorbate; $\mathrm{G}$ : stored in a mixture of crushed ice, $3 \% \mathrm{NaCl}, 0.05 \%$ Na-polyphosphate and $0.05 \% \mathrm{Na}$-pyrophosphate.

*** see Table 1 .

5) M. B. Faulkner, B. M. Watts, and H. I. Humm: Food Res., 19, 302-310 (1954).

6) D. Kakimoto and A. Kanazawa: Bull. Japan. Soc. Sci. Fish., 22, 471-475 (1956).

7) D. Kakimoto and A. Kanazawa: Bull. Japan. Soc. Sci. Fish., 22, 476-479 (1956).

8) D. Kakimoto and A. Kanazawa: Bull. Japan. Soc. Sci. Fish., 23, 454-457 (1957).

9) E. A. Fieger, M. E. Bailey, and A. F. Novak: Food Tech., 12, 297-300 (1958).

10) M. E. Bailey and E. A. Fieger: Food Tech., 8, 317-319 (1954).

11) L. Farber: Food Tech., 8, 503-505 (1954).

12) E. A. Fieger, M. E. Bailey, and A.F. Novak: Food Tech., 10, 578-583 (1956).

13) S. Nakamura and K. Kita: Monthly Report of Hokkaido Fish. Res. Inst., 31, 31-38 (1964).

14) N. Tsukuda and K. Amano: Bull. Tokai Reg. Fish. Res. Lab., No. 72, 9-19, (1972).

15) H. Yamanaka, T. Kikuchi, and K. Amano: Bull. Japan. Soc. Sci. Fish., 43, 115-120 (1977).

16) C. Y. Chung: Natl. Sci. Council Monthly, R.O.C., 5, 334-342 (1977).

17) C. Y. Chung and H. C. Chen: Natl. Sci. Council Monthly, R.O.C., 5, 534-540 (1977).

18) C. Y. Chung and J. L. Lain: Natl. Sci. Council Monthly, R.O.C., 7, 1139-1146 (1979).

19) C. Y. Chung, J. L. Lain, and H. H. Lin: Natl. Sci. Council Monthly, R.O.C., 8, 68-75 (1980).

20) K. A. Savagaon, V. Venugopal, S. V. Kamat, U. S. Kumta, and A. Sreenivasan: J. Food Sci., 37, 148-150 (1972).

21) K. A. Savagaon, V. Venugopal, S. V. Kamat, U. S. Kumta, and A. Sreenivasan: J. Food Sci., 37, 151-153 (1972).

22) U.S. Kumta, S. S. Mavinkurve, M. S. Gore, P. L. Sawant, S. V. Gangal, and A. Sreenvasan: $J$. Food Sci., 35, 360-363 (1970). 
23) M. Akiba, E. Tanikawa, and Y. Fujii: Food and Agriculture Organization, 115, 39-43 (1971).

24) W. C. Wang: Master Thesis, Natl. Taiwan Coll. Marine Sci. \& Tech., Taiwan, 1982, pp. 18-39.

25) Association of Official Analytical Chemists: Official Methods of Analysis, 12th ed., AOAC, Washington D. C., 1975, pp. 317-318.

26) M. L. Speck: in "Compendium of Methods for the Microbiological Examination of Foods", American Public Health Association, Washington D. C., 1976, pp. 507-520.

27) B. F. Cobb III, C. Vanderzant, M. O. Hanna, and C. S. Yeh: J. Food Sci., 41, 29-34 (1976).

28) J. R. Iyengar, K. Visweswarish, M. N. Moorjani, and D.S. Bhatia: J.Fish. Res. Bd. Canada, 17, 475-485 (1960).

29) B. Y. Chiang: Food Industry (Taiwan), 12, 4246 (1980).

30) B. F. Cobb III, A. Inelda, and A. T. Charles Jr.: J. Food Sci., 38, 431-436 (1973).

31) B. F. Cobb III and C. Vanderzant: J. Food Sci., 40, 121-126 (1975).
32) F. E. Cunningham: J. Food Sci., 44, 863-868 (1979).

33) M. C. Robach and F, J. Ivory: J. Food Protection, 41, 284-288 (1978).

34) M. C. Robach: J. Food Protection, 42, 855-861 (1979).

35) E. C. To and M. C. Robach: Poultry Sci., 59, 726-730 (1980).

36) S. T. Jiang, T. C. Lee, and C. O. Chichester: 42nd IFT Annual-Meeting Abs. No, 433, Institute of Food Technologists. 1982, pp. 188.

37) W. J. Dyer: in "Freezing and Irradiation of Fish", (ed. by R. Kreuzer), Fishing News (Books) Ltd., London, 1969, pp. 167-171.

38) A. H. Sutton: in "Freezing and Irradiation of Fish", (ed. by R. Kreuzer), Fishing News (Books) Ltd., London, 1969, pp. 172-178.

39) S. T. Jiang, M. S. Chen, and S. S. Chiang: J. Fish. Soc. Taiwan, 6, 13-19 (1979).

40) R. Fatima, B. Farooqui, and R. B. Quadri: $J$. Food Sci., 46, 1125-1131 (1981). 